\title{
RISE AND FALL OF JACOB ZUMA
}

\section{Vladimir Shubin ${ }^{1}$}

\section{Introduction}

In May 20I4 I suddenly received a telephone call from the South African Embassy in Moscow, then an official invitation signed by Jacob Zuma followed: he wanted me to be present at his second inauguration. Unfortunately I failed to do it, I was still recovering from a surgical operation, but the very fact was significant, not because I had been involved, but because it symbolized friendly relations that existed between the South African president and those in Russia who took part in supporting the long struggle against the apartheid regime.

I read and heard later that the inauguration ceremony was quite successful. Two weeks earlier the African National Congress headed by Zuma received $62.15 \%$ votes in general election. That was $3.7 \%$ less than in 2009 , but still quite impressive. The Congress of the People, the party created by those in the ANC who opposed Zuma, suffered a debacle, it received $0.67 \%$. Although, a "leftist" party, the Economic Freedom Fighters (EFF) received an impressive result for a new structure, $6.35 \%$ votes, and the main opposition, Democratic Alliance increased its result by $5.5 \%$ to $22.23 \%$ (Election Resources 20I4), but it in no way they threatened the dominance of the ANC.

True, Zuma first term witnessed some achievements both in domestic and in foreign policy. The ambitious National Development Plan «Our future - make it work. 2030» was adopted, and South Africa joined the association of leading "non-Western" countries - Brazil, Russia, India and China, transforming BRIC into BRICS. The South African President chaired the 5th BRICS summit in eThekwini (Durban) in March 20I3, and at the initiative of South Africa, a forum for dialogue with African leaders on the theme "Unlocking Africa's potential: BRICS and Africa Cooperation on Infrastructure"

I Principal Research Fellow of the Institute for African Studies of the Russian Academy of Sciences and Research Fellow, Centre for Military Studies, Slellenbosch University. E-mail: vlgs@yandex.ru. 
was also held during the summit, which was attended by heads of state and government and heads of African continental and regional organizations.

Let us recall that in late 2007 , Jacob Zuma came to the leadership of the ANC, when at the national conference of this party he won over the then president of the country Thabo Mbeki, having received the support of $60 \%$ of delegates. In 2009, after the general election Zuma confidently took over as president of South Africa, having been elected by the ANC majority in parliament.

Zuma's way to presidency was rather hard. "A simple man" - that is the term Jacob Zuma was often characterised ${ }^{2}$. Indeed, he was born in a village in KwaZulu-Natal and according to the majority of sources never received formal education, doing odd jobs to help his family after his father's death and teaching himself how to read and write.

Zuma joined the ANC in 1959 and the armed organization, Umkontho we Sizwe in 1962, soon after its formation by the ANC and South African Communist Party. The next year he was arrested with a group of young Africans on the way abroad for military training and sentenced to ten years imprisonment.

After the release in I973, Zuma worked in the ANC underground structures in KwaZulu-Natal, but two years later had to go into exile. Before long Zuma became popular in the ranks of the liberation movement and was elected to the ANC National Executive Committee in 1977. Soon, he was included in the group of ANC leaders, who underwent training in the Soviet Union (S.A. History 20I7)

He was initially based in Swaziland and Mozambique and remained in Mozambique even when most of the ANC leaders had to leave after the signing of the notorious Nkomati Accord ("Agreement on non-Aggression and Good Neighbourliness between Mozambique and South Africa") by presidents Samora Machel and Peter Botha on I6 March I984. He was involved in "sensitive" activities, maintaining contact with the ANC underground in South Africa. I recall that when our delegation was leaving Lesotho in I984, at the last moment, at the airport, a councilor of the newly established Soviet embassy passed me an envelope that ANC comrades asked to deliver to their

2 The irony is that former minister Ronnie Kasrils used these very words for his recently published very critical book about Zuma.

3 The group was headed by Alfred Nzo, Secretary-General and included such prominent persons as Sindiso Mfenyana, Reginald September and Dulcie September; later ANC representative in Paris killed by unknown assassin. The course was held at the Training Centre of the Soviet Defence Ministry, even if some fans of sensations claimed that he studied in "the KGB school for sabotage and terrorist activities" (https://ria.ru/world/20I80215/I5I465393I.html) 
colleagues in Mozambique. Moreover, the name of the recipient, Jacob Zuma, was marked on it. I carried a diplomatic passport, but on the way to Maputo the plane was to land at Matsapa airport in Swaziland, practically controlled by Pretoria's security, while Moscow had no diplomatic relations with that country. "On the other hand," I thought, "perhaps this letter can save somebody's life, so I have to take the risk."

When Zuma had to leave Mozambique on Pretoria's demand he joined the ANC HQ in Lusaka, Zambia. There in 1987 he was appointed deputy head of the ANC Department of Intelligence and Security, having conceded the top post to Joseph Nhlanhla, future South African Minister of Intelligence Services.

In this capacity he took part, often together with Thabo Mbeki, in confidential discussions with Pretoria regime's representatives and was a member of the ANC team who were the first to legally come to South Africa on March 2I I990 after the unbanning of this organization.

At the first legal national conference in Durban in July I991 Zuma was elected deputy to the ANC new Secretary General Cyril Ramaphosa. However Zuma political work was concentrated in his native KwaZulu-Natal. The Inkatha Freedom Party of Gatsha Buthelezi won the I994 election there, but Zuma became a member responsible for Economic Affairs and Tourism in the province's Executive Committee, formed on a coalition basis. (Many believe that the election was rigged in favour of the Inkatha. but the ANC top leadership decided not to question the results for the sake of peace in the province).

As the ANC chairperson in Kwazulu-Natal he did a lot for the rapprochement with the Inkatha and establishing lasting peace in the province. From 1994 he combined his post with the position of national chairperson of ANC and in 1997 he was elected the ANC Deputy President. Then two years later, after the second general election new South African President Thabo Mbeki appointed Zuma his deputy.

Zuma was regarded as a future heir of Mbeki in the ANC and state presidency, however soon he faced troubles. In 2002 Zuma was implicated in a major scandal, in connection with the trial of his close associate and financial advisor (and former underground operative) Schabir Shaik, who was accused of "corruption, fraud, theft of company assets, tax evasion and reckless trading" in the case connected with a so called "arms deal"4. On 23

4 The name used by South African mass-media for the Strategic Defence Acquisition, a South African military procurement programme. It involved a US\$4.8 billion (R30 billion in 1999 rands). 
August 2003 Bulelani Ngcuka, then the head of the National Directorate of Public Prosecutions told journalists: "We have concluded that, whilst there is a prima facie case of corruption against the deputy president, our prospects of success are not strong enough. That means that we are not sure if we have a winnable case. Accordingly, we have decided not to prosecute the deputy president" (News 24 2003).

That statement was hardly fair and many in South Africa saw it as an example of "conspiracy" against Zuma. He accused the prosecution of finding him guilty without having the necessary evidence (IOL 2003). Other examples followed, per instance the Schabir Shaik's trial was presided by Hilary Squires; a retired judge, former Rhodesian MP and even a minister in Jan Smith government in Rhodesia, was brought in specifically do it.

Therefore when after Sheik's conviction Thabo Mbeki "released" Zuma of his duties as Deputy President on I4 June 2005, there was a strong belief that Zuma was wrongly treated and two months later at the ANC National Council meeting his opponents failed to remove him from the post of the party's "second-in-command". Then when in August 2005 the investigators team searched Zuma's houses and his lawyer's premises and seized 93 oo documents; in his home in a Johannesburg suburb they almost clashed with the VIP protection unit (Namibian 2005) .

However it was not the end of Zuma's troubles. In December 2005, Zuma was charged with raping a younger woman, Fezekile Kuzwayo, a daughter of his old comrade. Zuma pleaded not guilty and in May 2006 was acquitted. Moreover, rumors were widely spread by his supporters that the whole episode was another conspiracy against him. I recall how my former colleague, a prominent African professor tried to convince me that the lady had been trained during three month to seduce Zuma.

The suspicion about anti-Zuma conspiracy was heated up by the circulation of e-mail messages, attributed to his opponents. The investigation, ordered by Ronnie Kasrils, minister of intelligence, proved they were hoax but far from everybody believed it.

A decisive battle for the ANC Presidency took place at the ANC National conference in Polokwane (former Pietersburg) in December 2007. It appears that Thabo Mbeki made a mistake to stand for the third term as the ANC President; although it is allowed by the party constitution, it looked like "clinging to power". By that time Zuma's supporters formed a so called "coalition of the wounded" (named after the notorious "coalition of the willing" during the US and UK aggression against Iraq in 2003). It consisted of the persons who had been one or another way offended or upset by Thabo Mbeki. However, another reason for delegates to support Zuma was more important: 
he was considered as "a man of the people" as distinct from Mbeki who was often regarded aloof and "moderate", pursuing "neoliberal" policy. Therefore Zuma was supported in particular by the SACP and Congress of South Africa Trade Unions (COSATU) as well as by the ANC Youth League. On I8 December Zuma won over Mbeki with convincing majority of delegate votes - 2329 to I505 (IOL 2007).

In that period the corruption charges against Zuma were still "simmering". Zuma had to appear in the Court on 29 June 2005 on two counts of corruption (The Guardian 2005), then an investigation was extended to include fraud, however on 20 September 2006 the case was stroked for "technicality", on the grounds that the State had charged Zuma before properly investigating and preparing its case against him (S.A. History 2007).

Nevertheless, just a couple of weeks after Zuma's victory in Polokwane, corruption charges against him were reinstated (The Guardian 2009). However on I2 September 2008, Judge Chris Nicholson of the Pietermaritzburg High Court "threw out the prosecution" (again on procedural ground), and moreover, he said that the decision to prosecute Zuma appeared to have been "politically motivated" (The Guardian 2008). Addressing about ten thousand supporters outside the court house, jubilant Zuma said the case was a lesson to anyone who abuses power. It is "a victory for democracy". However again it was not the end of the story.

Mbeki appealed the Nicholson verdict, and next February a Supreme Court of Appeal bench unanimously dismissed Nicholson's Zuma judgment with contempt (Mail \& Guardian 2009), but it was too late. On I9 September 2008 the ANC National Executive Committee at a meeting that went on until early morning decided to "recall comrade Thabo Mbeki before his term expires"; and ANC secretary-general Gwede Mantashe told reporters at a press conference after the decision was taken that the Nicholson judgment played a major role in it. Mbeki himself said later: "That was a decision not made by the ANC but by Judge Nicholson and the ANC acted on it" (IOL 2009) .

Several members of Mbeki's government resigned following him, including Deputy President Phumzile Mlambo-Ngcuka, Dr Essop Pahad, minister in the Presidency and Ronnie Kasrils, minister of intelligence services.

In the author's opinion this episode is a convincing evidence of the defectiveness of the "most democratic" constitution of South Africa: without violation of its clauses a single person by taking a wrong decision changed the destiny of the country.

However Zuma could not be elected state president at once, because he surrendered his parliamentary seat in 2005 , and the top post was occupied 
by his deputy in the ANC, Khalema Motlanthe. It was pre-decided that Motlanthe's term in the office would be short, till the next election, scheduled for 2009 , but in any case he served his country with dignity and efficiency.

Zuma's time came on 6 May 2009 when parliament elected him President of the Republic of South Africa. Zuma's critics reminded that as Deputy President during six years he hardly opposed so called "neoliberal" course of Mbeki's government and that both of them, then members of the Politbureau, left the Communist Party in I990, when it became legal and there was no place for secret membership anymore. Nevertheless his election was generally regarded as a "turn to the left", or, as a leader of the SACP told me, "a potential for the left turn". This even created some concern in the right-wing circles both in South Africa and beyond about the country's future, especially of its economy.

Initially, president Zuma, an easily accessible person who often used progressive rhetoric was quite popular. Moreover, he did appoint some "lefties" to his cabinet, including Dr Blade Nzimande, SACP General Secretary. In December 2012 at the ANC congress in Mangaung (Bloemfontein) Zima received even more support than five years earlier - more than $70 \%$ of delegates. However, disappointment in the results of the ANC government's rule has been growing even in the ranks of the ruling party. In 20I2, the ANC conference clearly expressed concern about the low pace of social and economic reforms, which found expression in the adoption of the provision on the "second phase of the transition from apartheid colonialism to a national-democratic society" that "will be characterized by decisive actions to effect economic transformation and democratic consolidation, critical both to improve the quality of life of all South Africans, and to promote nation-building and social cohesion." ${ }^{5}$ According to Zuma, in the course of it there had to be a "radical shift" towards greater state involvement in the economy, especially in the mining sector.

However, on the contrary during the second term of "Zuma's rule" the political and economic situation in the country became more complicated and the role of the state was weakened. Yet one acute social problem in South Africa was and remains xenophobia. For the most part, it is caused by economic reasons, and periodic outbreaks of violence against foreigners, mainly labor migrants from African countries, were a consequence of high unemployment.

In its election campaign in 20I4, the ANC actively used two jubilees

5 Declaration Of the 53rd National Conference of the ANC. http://www.anc.org.za/events. php?t=53rd\%20National\%20Conference\%20-\%20Mangaung 
- its centennial, celebrated throughout 20I2, and the 2oth anniversary of the establishment of a democratic system in South Africa in April I994. But in the political vocabulary, especially among the opponents of the government, two other notions prevailed - Nkandla and Marikana.

In the first case, it concerned the construction of several facilities visitors' centre, kraal, poultry house, swimming pool - at Jacob Zuma's private state expense estate in his homeland, in Nkandla, in KwaZulu-Natal province. Almost 450-page report of Public Protector (ombudsman) Thuli Madonsela stated that part of the expenses for the construction could not be justified according to the South African law on national key points and suggested that Zuma at least partially pay them into the treasury. However, later the police minister Nathi Mthethwa, who was responsible for the "key points", said that in the report of Mandosela the expenses were exaggerated fivefold, and that in any case, the president should not compensate them. His position was supported by the ANC majority of members of parliament. So the issue was "frozen" for some time, but "exploded" later, when on March 3I, 20I6, the South African Constitutional Court on the suit of the opposition EFF unanimously decided that the demand of Public Protector was valid and binding for execution, and the resolution of the parliament, which supported the president, was incompatible with the constitution and illegal. Moreover, the court also ruled that, having failed to comply with this order earlier, the president violated the obligation to "uphold, defend and respect" the Constitution (News 24 20I6), and this gave rise to another attempt to oust Zuma, although the parliamentary majority - ANC members - did not allow to do it.

In the second case, it was a real tragedy. On August I6, 20I2, near the platinum mine of Marikana in the North-West Province of South Africa, 34 persons were killed by police bullets and 78 workers were injured, when they participated in the strike demanding pay increase. It happened after ten people had been killed, including two policemen and two security guards of the "Lonmin" company. This tragedy caused a huge resonance in the country; it was compared to the shooting of a demonstration of Africans in Sharpeville in I960. Police actions were severely criticized.

Soon another blow was delivered on President's prestige. Before the 2009 election, on April I the National Prosecuting Authority dropped charges against Zuma that included 783 (!) episodes of "corruption, fraud and extortion" but it proved to be not for good (Politics Web 2009). The High Court of Gauteng Province on April 29, 2016 overruled this decision. Moreover, the court ruled that Mokotadi Mpshe, who was then the National Director of Public Prosecutions, acted under pressure.

Then the relations between President the Gupta family were brought 
to a public scandal. Immigrants from India, the Gupta brothers founded business in South Africa in 1993, having built an entire empire in 20 years, engaged in a variety of activities. They established close ties with Jacob Zuma before he became president; his close relatives - one of his wives ${ }^{6}$, a son and a daughter - held high positions in the companies belonging to the Gupta clan, who enjoyed various preferences and privileges from the South African government.

The first major scandal involving the Gupta brothers occurred in 2013, when a chartered plane, flying from India with guests to the wedding of their niece, despite the rules, was allowed to land at the military airfield Waterkloof near Pretoria, reserved for arriving heads of state and diplomatic delegations. More serious events occurred at the end of 20I5 when unexpected dismissal on December 9 of the Minister of Finance Nhlanhla Nene, who was replaced by the little-known "backbencher" David van Rooyen, was associated with the Gupta family. This Zuma's decision adversely affected the country's financial system, causing a sharp weakening of the rand and a cheapening of South African assets. The immediate loss to the country was R500 billion, and the actual loss may turn out to be a lot more (BizNews 20I6). There were also reports that, shortly before, a number of persons who supposedly knew about the upcoming events had relied on lowering the rate of rand. They took rands to buy dollars, and when the rand fell, they exchanged dollars back for rand, which brought them several billion in profits. Moreover Msebisi Jones, Deputy Minister of Finance, publicly stated that on the eve of Nene's resignation the Gupta brothers offered him the post of minister (Mail \& Guardian 20I6) . Zuma insisted in the parliament that "no minister was appointed by the Guptas or anyone else" (News 242016 ), but protests, especially on the part of business structures, were so powerful that in four days he was forced to replace the newly appointed minister with Pravan Gordan, who previously held this post in 2009-20I4.

The president tried to distance himself from the Gupta family, but his reputation was irreparably damaged, and in the South African political vocabulary a new term appeared - "state capture," meaning the use of the state apparatus and state property for personal purposes. Thuli Madonsela had a good reason to begin new investigation that finally resulted in report ironically titled "State of Capture".

In this situation, Jacob Zuma not only became a target for criticism, but various political forces began to call for his resignation, including those,

6 Zuma's private life is beyond the theme of this article. We will just mention that he married six women and according to mass-media by May 2019 had 22 children from II women and was going to marry one more wife, 24 years old, who just delivered his child. 
who supported him earlier against Mbeki. The most radical position, as usual, was taken by the EFF that demanded also the dissolution of the parliament and the new general elections. Direct appeals to the president to step down were heard from Ahmed Kathrada, sentenced with Nelson Mandela to life imprisonment, as well as from other ANC veterans and religious figures. A group of military veterans, top commanders and commissars of the Umkonto we Sizwe - ANC People's Army - urged the leadership of the party "to assess... the wisdom to continue with Comrade J Zuma at the helm of both the ANC and the State. We are of the view, that for the sake of the ANC and the country a dignified exit should be negotiated with Comrade J Zuma".

Under these circumstances, local elections in August 20I6 became of national importance. In general, the ruling party predictably won a victory; however, some called it "Pyrrhic": although the ANC gained control over more than $78 \%$ of the country's administrative districts, it received only $54.59 \%$ of the vote. This was the worst result since 1994 and almost $8 \%$ less than in previous local elections. At the same time, the main antagonist of the ANC, the Democratic Alliance, although it received twice less, $27.02 \%$ of the vote, strengthened its control over the parliamentary capital of the country - Cape Town and received a relative majority of seats in the administrative capital of the country Tswan (Pretoria) (although the gap was small - 93 seats for the DA against 89 for the ANC) and in the large municipality of Nelson Mandela Bay (Port Elizabeth) in the Eastern Cape Province, traditionally considered ANC stronghold. In Johannesburg, ANC managed to retain the relative majority of votes, but it lost its previous majority of seats in the city council. EFF received only $2 \%$ more votes than in the national elections in 20I4, although they were expecting to double or even triple the number. But in the coming, as the South African newspapers wrote, was "the era of coalitions": despite the third place with $8.24 \%$ of the vote, "Economic Freedom Fighters" got a chance to become a "kingmakers" and successfully implemented it.

Thus, with the assistance of EFF and some small parties, DA managed to gain control not only over Tshwane and Nelson Mandela Bay, but also over Johannesburg, the economic capital. No matter how dramatic it was for the ANC to lose control over these major cities, the moral blow that this party was forced to endure was no less painful. Zuma has repeatedly stated earlier that the ANC will rule "until Jesus comes", so after the election, offensive jokes became popular: "Zuma went to meet Jesus at O.R. Tambo International Airport," "Jesus came for Zuma in Tshwane", etc.

The significant loss of ANC votes can be explained not only by complex social and economic problems (minimal GDP growth, high unemployment, wide-spread poverty), but also by the factional struggle within this party, and 
especially corruption scandals that directly affected Jacob Zuma. In the runup to the elections, there were two opposing views in the ANC. Some believed that Zuma turned into an "albatross on the neck" of the party; others believed that the resignation of the leader on the eve of the election would create chaos and weaken the position of the ANC. The second point of view won, but the election results led to the renewal of demands for changes in the leadership of the ANC. Many prominent and ordinary ANC members blamed the party leader for the failure.

The culmination of the events was the funeral of Ahmad Katrada, who died on March 28, 20I7. It was attended by almost all the top leaders of the ANC, except for Zuma, who was reportedly not wanted by the family of the deceased. The situation was heated the day before, when president, without any explanation, withdrew from the foreign trip the country's popular finance minister, Pravan Gordhan and his deputy Msebizi Jonas, who were in open conflict with the Gupta clan. Zuma predecessor Khalema Motlanthe in his funeral speech directly quoted Katrada's letter to the president with the call to resign?

Zuma's, so to say, reply was one more, itth since he became president, reshuffle of the cabinet. In particular, he fired Gordhan and Jonas, without consulting with other senior leaders of the ANC and the country. Zuma's deputy in the party and state Cyril Ramaphosa, the general secretary of this party, Gwede Mantashe, and its general treasurer, Zweli Mkhize, openly expressed disagreement with such actions.

For the first time, the issue of Zuma's resignation at the meeting of the ANC National Executive Committee was put up in November 2016, although it did not receive the support of the majority. The same happened with the non-confidence vote in April 2017 proposed again by the opposition in parliament, although for the first time it was supported by some of the parliamentarians from the ANC; and the two ANC allies in the "tripartite alliance" - the SACP Communist Party and COSATU demanded his resignation.

Zuma managed to delay the execution of the court decision on his criminal case and the implementation of the decision to establish an independent legal commission to investigate the charges contained in the report on "state capture", but the moment of reckoning was approaching - the ANC national conference was scheduled for December I6-20, 2017.

Seven candidates were nominated for the presidency of the party, including Cyril Ramaphosa and Dr Nkosazana Dlamini Zuma, a former minister and from 2012 to 2017 chair of the African Union Commission. Both can-

7 Hartley R. The story of the very political funeral of Ahmed Kathrada. 
didates were well-deserved, but Nkosazana's marriage to Zuma as well as his public support for her were detrimental. Although they divorced almost 20 years earlier, and at ANC conference in 2007 she was a candidate for the post of ANC chairperson on Thabo Mbeki' "slate", her opponents and the media referred to her as Zuma's "ex-wife". On December i6 Zuma announced the gradual introduction of free higher and professional education for students from families whose annual income does not exceed 350 thousand rand. This basically satisfied the demand of participants of student's protests in 20I520I6, but since such a decision was made public on the day of the opening of the ANC conference, it was regarded as the last minute attempt to help Nkosazana.

Ramaphosa won an undoubted victory in the election of the president of the ANC, although with a slight advantage, (2 440 votes against 226 I votes for Dlamini-Zuma) (BizNews 20I7), but among the six top leaders of the ANC and among the 80 members of the National Executive Committee, his obvious supporters occupied only about half of the seats. However many of his recent opponents began to move to the new leader's side; a vivid example is David Mabuza, then the ANC Chair and Premier in Mpumalanga province. Although he was regarded earlier as Jacob Zuma's supporter, it looks like he provided vital votes of delegates from "his" province for Ramaphosa and was "rewarded" by the post of Deputy President.

After the conference appeals to Zuma to resign intensified, as the retention of the post of president would weaken the ANC's chances of winning the upcoming parliamentary elections not later than May 20I9. However when the ANC new top leadership tried to pursue him to voluntarily do it, he remained resilient.

So, on February I3 the ANC National Executive Committee took a decision to recall him. That was similar to the events of September 2008, but as distinct from Thabo Mbeki Zuma was still clinging to power. He insisted on several months delay to chair the summits of the Southern African Development Community and BRICS, to be held in South Africa.

To assess his action one has to take in mind that in South Africa to leave "in a good way", obtaining a guarantee against criminal prosecution and retaining property for the president and his family (as was done recently for Robert Mugabe in Zimbabwe) is practically impossible given strict legal norms. So it was reported that Zuma had put forward, as a condition of his resignation, payment of his future (terribly high!) expenses for lawyers and other legal costs.

Zuma agreed to leave only after it became clear that non-confidence vote scheduled on February I5 was going to be supported by both the opposi- 
tion and his own party. Zuma took this step late on the previous evening, addressing the nation on TV. Having underlined his disagreement "with the decision of the Leadership of my organisation", Zuma, nevertheless announced his resignation "as President of the Republic with immediate effect". Referring to "the instances of violence that have occurred because of the different views among members of our organization outside our headquarters, Luthuli House" he proclaimed: "No life should be lost in my name and also the ANC should never be divided in my name" (News24 20I8) .

In accordance with the Constitution of South Africa, Ramaphosa immediately became the acting president of the country. The election of a new president was to be held within 30 days, but the day after the resignation of Zuma, on February I5, the National Assembly unanimously elected Ramaphosa. Only deputies from the EFF left the chamber, declaring the illegality of the parliament, but they also joined the standing ovation after Ramaphosa's "State of the Nation" address next day.

Thus, the change of the supreme power in South Africa took place purely democratically, without any interference by the security forces. None of the ministers who were considered supporters of Zuma, resigned.

The end of the prolonged uncertainty was welcomed both within South Africa and beyond. The credit ratings of South Africa were lowered by two of the top three international agencies primarily because of the political situation in the country, but its stabilization after Ramaposa's arrival to the country's leadership is helping to raise them. There has already been a noticeable strengthening of the South African rand, and the rate on government bonds of South Africa has decreased. The main and urgent task facing the new president is the fight against corruption, which has already begun. For example, an arrest warrant has been issued for one of the brothers Gupta, who is hiding from the police.

It can be assumed that in the near future the focus of South Africa's leadership, headed by Ramaphosa, will be on domestic policy. It is noteworthy that only two paragraphs were devoted to foreign policy in Ramaphosa's State of the Nation Address; one of them spoke of free trade zones on the African continent, and the other about the South African presidency in the BRICS (South African Government 20I8).

The entry of South Africa into the BRICS was the main achievement of South Africa's foreign policy under Zuma. Having publicly stated about three attempts to poison him, Zuma emphasized that he "almost died just because South Africa joined Brics under my leadership" (The Citizen 20I7). There is no reason to expect significant changes in South Africa's foreign policy after the election of Ramaphosa, although the "anti-imperialist" rhetoric 
that characterized the previous president (which could not prevent, for example, the expansion of military cooperation with the African Command of the United States) may be weakened.

The Department of International Relations and Cooperation two weeks before the resignation of Zuma has already announced an extensive program of events for the period of the country's chairmanship in the BRICS. However, the difference in the priorities named in this programme and in Ramaphosa's programme statement deserves attention. In the first case they were for: establishment of a Virtual Vaccine Research Platform for Collaboration with BRICS vaccine innovation and development partners, establishment of a BRICS Gender and Women's Forum, establishment of a Working Group on Peacekeeping and leveraging the Strategy for BRICS Economic Partnership as linked to the Fourth Industrial Revolution" (Republic of South Africa 20I8), while Ramaphosa named only one - "the promotion of value-added trade and intra-BRICS investment into productive sectors" (Times Live 20I8). Hence we can conclude that the new president, first of all, hopes that this association will contribute to solving the problems of the South African economy.

As for the political views of Ramaphosa, who at one time openly advocated socialism, and then became a major businessman, he formulated them in a rather peculiar way: "I am a capitalist with a socialist instinct" (Mail \& Guardian 2015). It remains to be seen how these two notions will expressive themselves during his presidency.

Ramaphosa is characterized by a desire to solve problems through negotiations, avoiding extreme measures. For example, he spoke in 2008 against the recall of Thabo Mbeki as president, and after his election as ANC president patiently negotiated with Jacob Zuma for his resignation and later even arranged a farewell cocktail party for the former president and members of his government (ENCA 20I8).

During the cocktail Zuma looked quite pleased with life, but it was hardly sincere. His departure from the state post lifted the brakes of the South African legal mechanism, and it soon came into action. Already on April 6 Zuma faced $\mathrm{I} 6$ charges that include fraud, corruption and racketeering in the High Court in Durban (Times Live 20I8). As before, he welcomed his supporters who carried posters "Hands off Zuma" and "Iо०\% innocent" (there are still a lot of them in his native province) with his favourite song "Umshini Wami ([Bring me] my machine-gun)" (Daily Maverick 20I8). But this time fortune is unlikely to be on his side. The next court session is scheduled for June 8, and the prosecutor's office named 207 state witnesses (The South African 20I8). So far, Shabir Shaik, who was released from prison "for health reasons" after serving just two years of ${ }^{5}$, is not amongst them, but he will 
testify in court if subpoenaed (WN 20I8). What will be the strength of his evidence that is regarded by media as a potential "explosion" and how many more "bombers" can join him? What will happen with Jacob Zuma? We have to wait to receive final answers and taking into account South African legal system, probably for years.

\section{REFERENCES}

BizNews. 2016. "Calculating Zuma's R50obn \#Nenegate blunder - Rand depreciation excluded". Available from: https://www.biznews.com/undictated/2016/03/05/calculating-zumas-r5oobn-blunder-the-effs-calculation-was-correct.

BizNews. 20I7. "UPDATE: Ramaphosa wins by a whisker, 3 of top 6 are Premier League faithfuls". Available from: https://www.biznews.com/ undictated/20I7/I2/I8/final-anc-vote-result-ramaphosa-wins.

Daily Maverick. 20I8. “Zuma's Day in Court: Matter postponed to June as cheering crowds pledge loyalty". Available from: https://www.dailymaverick.co.za/article/20I8-04-o6-zumas-day-in-court-matter-postponed-to-june-as-cheering-crowds-pledge-loyalty/\#.Wvv28SlFnAY.

Election Resources. 20I4. General Elections in the Republic of South Africa. Available from: http://www.electionresources.org/za/.

ENCA. 20I8. "GALLERY: Zuma in good spirits at farewell cocktail dinner". Available from: https://www.enca.com/south-africa/gallery-zuma-ingood-spirits-at-farewell-cocktail-dinner.

IOL. 2003. "NDPP found me guilty with no evidence: Zuma". Available from: https://www.iol.co.za/news/politics/ndpp-found-me-guilty-with-noevidence-zuma-III554.

IOL. 2007. "Party in Polokwane as Zuma sweeps to victory". Available from: https://www.iol.co.za/news/politics/party-in-polokwane-as-zumasweeps-to-victory-383197.

IOL. 2009. "I was hurt, says Mbeki”. Available from: https://www.iol.co.za/ news/politics/i-was-hurt-says-mbeki-462592.

Mail \& Guardian. 20I8. “Unembargoed: May 4 to Io”. Available from: https:// mg.co.za/article/2018-05-07-00-unembargoed-may-4-to-Io.

Mail \& Guardian. 2009. "Judge Nicholson red-carded by SCA". Available from: https://mg.co.za/article/2009-OI-I2-judge-nicholson-redcarded-by-sca. 
Mail \& Guardian. 20I5. "Is Ramaphosa still a shoo-in?". Available from: https://mg.co.za/article/20I5-o9-Io-is-ramaphosa-still-a-shoo-in.

Mail \& Guardian. 20I6. "'Guptas offered me Finance Minister position' - Mcebisi Jonas". Available from: https://mg.co.za/article/20I6-03-I6-guptas-offered-me-finance-minister-position-mcebisi-jonas.

Namibian. 2005. "Scorpions raid Zuma and Shaik's homes". Available from: https://www.namibian.com.na/index.php?id=II230\&page=archive-read.

News 24. 2003. "Zuma 'won't be prosecuted'". Available from: https:// www.news24.com/SouthAfrica/News/Zuma-wont-be-prosecuted-20030823.

News 24. 20i6. "President Zuma failed to uphold, defend the Constitution". Available from: https://www.news24.com/SouthAfrica/ News/president-zuma-failed-to-uphold-defend-the-constitution-concourt-20I6033I.

News 24. 20I6. "PARLIAMENT: No minister was appointed by the Guptas or anyone else - Zuma”. Available from: https://www.news24.com/ Video/SouthAfrica/News/watch-live-president-zuma-answers-questions-in-parliament-20I603I7-5.

News 24. 20I8. "READ: Zuma's resignation speech in full". Available from: https://www.news24.com/SouthAfrica/News/read-zumas-resignation-speech-in-full-20180215.

NPC Online. 20I8. "Should You Consider Long-Term Addiction Treatment?". Available from: http://www.npconline.co.za/.

Politics Web. 2009. "Why I decided to drop the Zuma charges - Mpshe". Available from: http://www.politicsweb.co.za/news-and-analysis/ why-i-decided-to-drop-the-zuma-charges--mpshe.

Republic of South Africa. 20I8. "Speaking Notes: Ambassador Anil Sooklal, South Africa's BRICS Sherpa during the BRICS Stakeholder Roundtable on the 29th January 2018 in Pretoria". Available from: http:// www.dirco.gov.za/docs/speeches/20I8/sookoI29.htm.

South African Government. 20I8. "President Cyril Ramaphosa: 20I8 State of the Nation Address". Available from: https://www.gov.za/ speeches/president-cyril-ramaphosa-20I8-state-nation-address-16feb-2018-0000.

S.A. History. 20I7. "Jacob Gedleyihlekisa Zuma". Available from: https:// www.sahistory.org.za/people/jacob-gedleyihlekisa-zuma.

The South African. 20I8. "Zuma trial: State releases names of 207 witnesses 
testifying, Shaik not listed". Available from: https://www.thesouthafrican.com/zuma-trial-state-207-witnesses/.

Times Live. 20I8. "Read Cyril Ramaphosa's first state of the nation address". Available from: https://www.timeslive.co.za/politics/2018-02-16-infull--read-cyril-ramaphosas-first-state-of-the-nation-address/.

Times Live. 2018. "Done in 20 minutes: Zuma fraud, corruption case postponed". Available from: https://www.timeslive.co.za/news/south-africa/2018-04-o6-done-in-20-minutes-zuma-fraud-corruption-casepostponed-to-june/.

The Citizen. 20I7. "Zuma reveals why 'they' poisoned him". Available from: https://citizen.co.za/news/south-africa/I6Io878/zuma-reveals-whythey-poisoned-him/.

The Guardian. 2005. "Zuma indicted on corruption charges". Available from: https://www.theguardian.com/world/2005/nov/05/southafrica. mainsection.

The Guardian. 2008. "Zuma court victory clears pathway to presidency". Available from: https://www.theguardian.com/world/2008/sep/i3/ southafrica.

WN. 20I8. "Rumour that I will testify in case against Jacob Zuma 'blows my mind', says Schabir Shaik". Available from: https://article.wn.com/ view/20I8/03/I9/Rumour_that_I_will_testify_in_case_against_Jacob_Zuma_blows_/.

\section{ABSTRACT}

In May 20I4 I suddenly received a telephone call from the South African Embassy in Moscow, then an official invitation signed by Jacob Zuma followed: he wanted me to be present at his second inauguration. Unfortunately I failed to do it, I was still recovering from a surgical operation, but the very fact was significant, not because I had been involved, but because it symbolized friendly relations that existed between the South African president and those in Russia who took part in supporting the long struggle against the apartheid regime.

\section{KEYWORDS}

South Africa; Politics; Jacob Zuma.

Received on May 05, 2018. Approved on June 24, 2018. 